\title{
ALTERATION IN COLOUR AND FUNGAL RESISTANCE OF THERMALLY TREATED OIL PALM TRUNK AND RUBBERWOOD PARTICLEBOARD USING PALM OIL
}

\author{
LEE, S H*; ZAIDON, A**; RASDIANAH, D**; LUM, W C ${ }^{*}$ and AISYAH, H A*
}

\begin{abstract}
Urea formaldehyde-bonded particleboard made from oil palm trunk (OPT) and rubberwood (RW) were soaked in palm oil for $24 \mathrm{hr}$ before thermally treated in oven at $180^{\circ} \mathrm{C}, 200^{\circ} \mathrm{C}$ and $220^{\circ} \mathrm{C}$. Colour changes and decay resistance against white rot fungus (Pycnoporus sanguineus) of the samples after thermal treatment were investigated. After thermal treatment, Lightness $\left(L^{*}\right)$ of the samples decreased and the extent of darkening increased along with increasing treatment temperature. Generally, RW samples became redder after heat treatment while OPT samples basically showed the same pattern except it became greener when treated at $220^{\circ} \mathrm{C}$. Yellowing (positive $b^{*}$ value) was observed at milder temperature and succeeded by bluing at higher temperature. Improvement in fungal resistance was observed for both OPT and RW samples. The weight loss of the untreated OPT and RW samples were $12.97 \pm 1.62 \%$ and $30.71 \pm 1.75 \%$, respectively. At $220^{\circ} \mathrm{C}$, the respective weight loss of OPT and $R W$ samples were $4.58 \pm 0.44 \%$ and $5.78 \pm 1.23 \%$. RW showed lower fungal resistance compared to that of the OPT. Strong correlations $\left(R^{2}>0.75\right)$ were found between weight loss and $\Delta E^{*}$ suggested that fungal resistance increased along with increasing $\Delta E^{*}$ values.
\end{abstract}

\section{Keywords: CIE L*a*b* system, biological durability, thermal treatment, weight loss, wood composites.}

Date received: 20 December 2018; Sent for revision: 17 March 2019; Accepted: 19 June 2019.

\section{INTRODUCTION}

Particleboard is one of the reconstituted panels mainly used for interior applications due to the fact that conventional particleboards are bonded with low moisture resistance urea formaldehyde resin (UF). Superior water and fungal resistance are

\footnotetext{
Institute of Tropical Forestry and Forest Products,

Universiti Putra Malaysia,

43400 UPM Serdang, Selangor, Malaysia.

E-mail: lee_seng@upm.edu.my

** Faculty of Forestry,

Universiti Putra Malaysia,

43400 UPM Serdang, Selangor, Malaysia.

‡ Institute for Infrastructure Engineering and Sustainable Management (IIESM),

Universiti Teknologi MARA,

40450 Shah Alam, Selangor, Malaysia.
}

not important for particleboards used in dry inner environment. Nevertheless, these particleboards in use should acquire some ability to withstand some occasional occurrence of wetting as it would facilitate the attack of fungus. A study by Chung et al. (1999) revealed that wood composites such as plywood, particleboard, medium density fibreboard and oriented strand board are prone to be attacked by wood-decaying fungi. White rot fungi are often reported to have caused higher weight loss to the samples as white rot consume both carbohydrates and lignin in the wood cell wall compared to the brown rot fungi that only consume carbohydrates. De Melo et al. (2015) reported in their study that the weight loss caused by white rot fungi on particleboard made from both rubberwood (RW) and bamboo are higher than weight loss by brown rot fungi. 
A number of treatments have been conducted in improving the biological resistance of particleboard. For instance, Reinprecht et al. (2018) incorporated nano-zinc oxide into melamine UF resin and the particleboard made from it exhibited a weight loss reduction of around $86 \%$ by brown-rot fungus, Coniophora puteana. Despite its effectiveness, application of nanomaterials is still a major concern as it may pose serious threats to human and environment. In contrast, thermal treatment, a green treatment method without application of toxic chemicals, is an effective method to improve the dimensional stability and biological durability of wood and its composites (Boonstra et al., 2007). Hakkou et al. (2006) recorded a significant improvement of thermally-treated beech wood in resistance against Coriolus versicolor and attributed the improvement to the hydrophobic nature, production of toxic compounds and degradation of hemicellulose of wood during heat treatment. Eucalyptus grandis wood heat treated at $180^{\circ} \mathrm{C}-220^{\circ} \mathrm{C}$ recorded a weight loss reduction of 16\%-82\% against Pycnoporus sanguineus (Calonego et al., 2010).

Thermal treatment involving oil has been reported to offer several advantages to the treated wood such as exclusion of oxygen during treatment process and more even and rapid transfer of heat into the wood samples (Lee et al., 2018a). Alder wood treated in soya oil at $180^{\circ} \mathrm{C}$ and $200^{\circ} \mathrm{C}$ for 6 $\mathrm{hr}$ and $10 \mathrm{hr}$ exhibited superior resistance against Postia placenta (Lacic et al., 2014). RW thermally treated in palm oil had enhanced fungal resistance due to changes in chemical constituents (Umar et al., 2016). Apart from that, oil heat treatment is also known to cause changes in colour of the treated wood samples. Colour of the treated samples becomes darker and more uniform. The changes in colour were reported to have strong correlation with fungal resistance (Dubey et al., 2012). As the darkening of wood are mainly caused by the production of coloured degradation products from hemicelluloses as well as extractives components, it can potentially be used as a good prediction tool for decay resistance of heat-treated wood (Candelier et al., 2016).

According to a review done by Lee et al. (2018a), there are basically three types of oil heat treatment, namely, oil heat treatment (OHT) by Company Menz Holz in Germany, bi-oleothermal process by France's CIRAD, and Royal treatment. All treatment methods involve the immersion of wood samples into vegetable oils to ensure rapid and even heat transfer into the core of the samples. In addition, the treated wood exhibited better strength owing to the weight percent gain resulted by oil uptake during the process. Study by Lee et al. (2018b,c) slightly differed from the above mentioned treatment methods where the samples were soaked into the palm oil prior to heat treatment. The chemical properties, dimensional stability and termite's resistance of oil palm trunk (OPT) and RW particleboard thermally treated with palm oil has been reported by Lee et al. (2018b,c). However, the effects of the thermal treatment on the colour changes and resistance against fungus have yet to be reported. This article reports the changes in colour and fungal resistance of the thermally treated particleboards made from OPT and RW. The feasibility of the heat-induced colour changes to serve as a prediction tool for the extent of decay resistance was also investigated.

\section{MATERIALS AND METHODS}

\section{Thermal Treatment of Particleboard}

RW and OPT particleboards bonded with $8 \%$ UF resin as specified in Lee et al. (2017) were used in this study. Vesawit edible palm oil (Yee Lee Edible Oils Sdn Bhd, Ipoh, Perak, Malaysia) was used to soak the particleboard samples before heat treatment in the laboratory oven. Before soaking in palm oil, the samples with dimensions of 50 $\mathrm{mm}$ long x $50 \mathrm{~mm}$ wide $\times 12 \mathrm{~mm}$ thick were ovendried in a laboratory oven set at $103^{\circ} \mathrm{C}$ for $24 \mathrm{hr}$. The oven-dried samples were soaked in palm oil for $24 \mathrm{hr}$. After $24 \mathrm{hr}$, the samples were taken out and heat treated in oven at $180^{\circ} \mathrm{C}, 200^{\circ} \mathrm{C}$ and $220^{\circ} \mathrm{C}$ for $2 \mathrm{hr}$. Heat treatment is typically conducted at the temperature levels ranging from $180^{\circ} \mathrm{C}$ and $260^{\circ} \mathrm{C}$, where lower temperatures only altered the material's properties insignificantly while higher temperatures would lead to undesirable degradation to the wood substrate (Lee et al., 2018a). Therefore, three treatment temperature levels, namely $180^{\circ} \mathrm{C}, 200^{\circ} \mathrm{C}$ and $220^{\circ} \mathrm{C}$ were chosen for this study. After the thermal treatment, the samples were conditioned in a conditioning room until constant mass was attained.

\section{Colour Measurement}

Colour of the treated and untreated particleboard samples were measured using Brightness \& Colour Meter (Model No. 68-50-00-0001, Messmer Instruments Ltd) through CIE $\mathrm{L}^{*} \mathrm{a}^{*} \mathrm{~b}^{*}$ system. The values were obtained from three points of the samples surface. The $\mathrm{L}^{*}$ axis represents Lightness where 0 represents black and 100 represents white. The $\mathrm{a}^{*}$ axis is green (represented by $-a)$ and red $(+a)$ while the $b^{*}$ axis is blue $(-b)$ and yellow $(+b)$. Colour variations induced by thermal treatment are expressed as the overall colour difference $\left(\Delta \mathrm{E}^{*}\right)$, are determined from Equation (1):

$$
\Delta \mathrm{E}^{*}=\left[\Delta \mathrm{L}^{* 2}+\Delta \mathrm{a}^{* 2}+\Delta \mathrm{b}^{* 2}\right]^{1 / 2}
$$




\section{Fungal Decay Test}

White rot fungus, Pycnoporus sanguineus, was used in the fungal decay test for both OPT and RW samples. The test blocks preparation procedures were conducted in accordance with ASTM D 201705: Standard Test Method of Accelerated Laboratory Test of Natural Decay Resistance of Woods. The $P$. sanguineus was collected from an infested pine stand from a pine plantation located in the Institute of Bioscience, Universiti Putra Malaysia, Serdang, Selangor, Malaysia. The collected fungi were then cultured in the Wood Deterioration and Treatment Laboratory at the Faculty of Forestry, Universiti Putra Malaysia. Five test blocks had a dimensions of $25 \mathrm{~mm}$ long x $25 \mathrm{~mm}$ wide x $12 \mathrm{~mm}$ thick were prepared for each treatment variable. A total of 40 samples were tested ( 2 species $\times 4$ temperature levels $x 5$ replicates). RW with dimensions of $35 \mathrm{~mm}$ long $\times 28 \mathrm{~mm}$ wide $\times 3 \mathrm{~mm}$ thick was used as feeder strip for inoculation of $P$. sanguineus. The steam sterilised particleboard samples were put on the feeder strips covered with mycelia and put on the top of the soil in each culture bottle. The test blocks were incubated for 16 weeks. At the end of the test, the samples were removed from culture bottles. The test blocks cleaned from fungal mycelium were then oven-dried until constant weights were attained. Each block was weighed and the percentage of weight loss for the test block was calculated using the Equation (2):

$$
\mathrm{WL}(\%)=100(\mathrm{~W} i-\mathrm{W} f) / \mathrm{W} i
$$

where $\mathrm{W} i$ is the initial weight of test block before exposure to fungi $(\mathrm{g})$ and $\mathrm{W} f$ is the weight of test block after exposure to fungi (g).

\section{RESULTS AND DISCUSSION}

\section{Colour Changes}

The visual appearances of both the RW and OPT particleboard after treated at different treatment temperatures are shown in Figure 1. Heat-induced darkening can be observed on the sample surfaces and the extent of darkening increased along with increasing treatment temperature. Alteration of wood colour due to thermal treatment could be caused by the migration of quinonnes, extractives, low molecular sugars and amino acids towards the samples' surfaces (Bekhta and Niemz, 2003). Salca et al. (2016) attributed the heat-induced colour changes to the degradation of lignin and hemicelluloses. Apart from that, oil uptake is also a factor that can contribute to the darkening effect of the samples as it forms an oil layer on the wood surface. Dubey et al. (2011) found that wood with higher oil uptake tended to have darker colour. Toker et al. (2016) suggested that, in a treating medium without presence of oxygen, caramelisation of soluble sugars produced from hydrolysed hemicellulose imparted darker colour to the wood.

The untreated OPT particleboard has lightness $\left(\mathrm{L}^{*}\right)$ of 59.93 , coordinate green-red $\left(\mathrm{a}^{*}\right)$ of 2.75 and coordinates blue-yellow $\left(b^{*}\right)$ of 6.40 . Meanwhile, the RW particleboard had the respective values of 47.44, 0.41 and 5.51. Average colour coordinates $\left(\Delta \mathrm{L}^{*}, \Delta \mathrm{a}^{*}, \Delta \mathrm{b}^{*}\right)$ and colour changes $\left(\Delta \mathrm{E}^{*}\right)$ as a result of heat treatment are tabulated in Table 1. Decrement in lightness $\left(\Delta \mathrm{L}^{*}\right)$ indicated the darkening effect induced by heat treatment. Lightness also represents the extent or severity of the thermal treatment. In this case, OPT particleboard seems to be more affected by the heat treatment as decrement in $\Delta \mathrm{L}^{*}$

Rubberwood
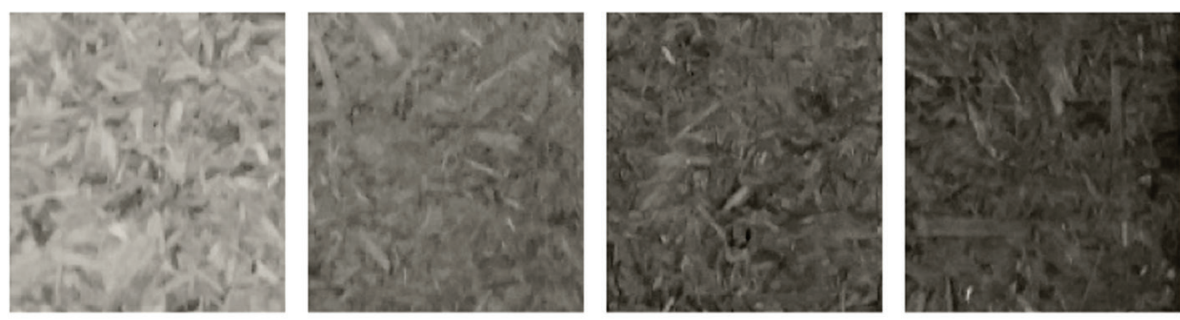

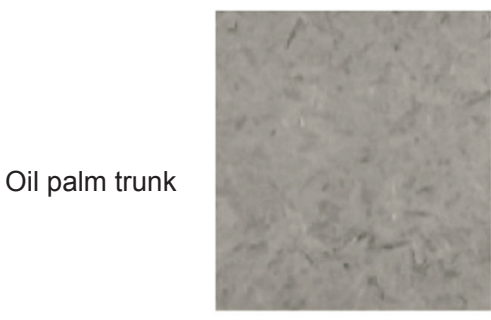

Control

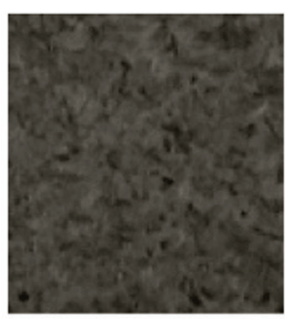

$180^{\circ} \mathrm{C}$

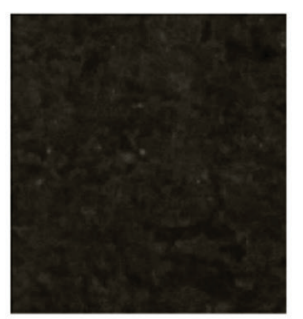

$200^{\circ} \mathrm{C}$

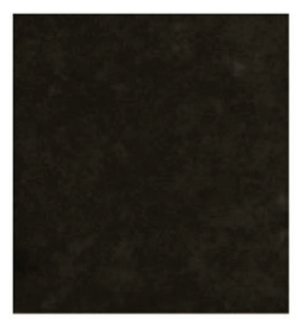

$220^{\circ} \mathrm{C}$

Figure 1. Visual appearance of rubberwood (RW) and oil palm trunk (OPT) particleboard as function of heat treatment temperature. 
was higher compared to that of the RW samples. Bektha and Niemz (2003) attributed the reduction in lightness to the degradation of hemicellulose, particularly pentosan.

For both OPT and RW samples, $\mathrm{a}^{*}$ and $\mathrm{b}^{*}$ values increased when the particleboards were treated at a milder temperature $\left(180^{\circ} \mathrm{C}\right)$. However, as the treatment temperature elevated, both values started to decrease and these findings were in line with study reported by Gonzalez-Pena and Hale (2009). Generally, wood becomes redder and more yellow when subjected to heat treatment. RW samples became redder after heat treatment as indicated by the positive $a^{*}$ values. Nevertheless, the reddening effect was attenuated as the treatment temperature increased. On the other hand, the OPT samples basically showed the same pattern as RW samples except it became greener when treated at $220^{\circ} \mathrm{C}$, as indicated by negative $a^{*}$ value. Yellowing (positive $b^{*}$ value) was observed as the sample treated at milder temperature and the effects were eventually succeeded by the bluing effects and the treated samples became bluer (negative $b^{*}$ value) when subjected to higher temperature. As a result, total colour changes $\left(\Delta E^{*}\right)$ for both OPT and RW increased along with increasing treatment temperature. The finding was in agreement with Srinivas and Pandey (2012) who reported similar trend for thermally treated RW and silver oak. In a study reported by Gonzalez-Pena and Hale (2009), the $\Delta \mathrm{E}^{*}$ is positively correlated with the amount of lignin. As thermal treatment generally increased the lignin content of the wood, $\Delta \mathrm{E}^{*}$ is increased correspondingly.

\section{Fungal Resistance}

Figures 2 and 3 display the visual appearance of the OPT and RW after 16-week exposure to white rot fungi, Pycnoporus sanguineus. From Figure 3 , it can be observed that the RW particleboard sample were fully covered by the white rot fungi. However, for thermally treated particleboard samples, the surfaces were clear of fungal inhibition, indicating that the thermal treatment has prevented the colonisation of fungi on the samples. It is interesting to note that the untreated OPT particleboard samples did not cover by the white rot fungi as RW particleboard did. This observation is well-correlated with the average weight loss of the samples caused by $P$. sanguineus as illustrated in Figure 4. The weight loss of the untreated OPT and RW samples were $12.97 \pm 1.62 \%$ and $30.71 \pm 1.75 \%$, respectively. The weight loss reduced as the samples treated at $180^{\circ} \mathrm{C}$ and the reduction increased along with increasing treatment temperature. At $220^{\circ} \mathrm{C}$, the respective weight loss of OPT and RW samples were $4.58 \pm 0.44 \%$ and $5.78 \pm 1.23 \%$. RW showed higher weight loss compared to that of the OPT. This might be attributed to the lower lignin content in OPT compared to RW. P. sanguineus is a selective white rot which only digests wood hemicellulose and lignin while leaving cellulose undegraded (Howell et al., 2009). OPT was reported to contains $18 \%-21 \%$ lignin (H'ng et al., 2011) while RW contains around 24\%-27\% lignin (Okino et al., 2010). Therefore, higher extent of growth was found on RW samples as they provide sufficient nutrient to the white rot fungi. In addition, RW is more hygroscopic in terms of swelling properties than OPT and therefore absorbs more water and creates a favourable environment for the growth of fungus (Sulaiman et al., 2012).

Improvement in fungal resistance of the heattreated wood samples could be attributed to: (i) change in nature of the wood from hydrophilic to hydrophobic, (ii) generation of fungus repressive extractives, (iii) alteration of wood constituents, and (iv) removal of hemicellulose (Kamdem et al., 2002). The enhancement in fungal resistance is temperature dependent where the higher the treatment temperature, the lower the mass loss. At higher temperature, higher amount of thermally labile hemicellulose was degraded. The removal of these hydroxyl groups make the wood hydrophobic and the capability of the wood to absorb moisture from the environment is reduced.

TABLE 1. COLOUR ALTERATION OF OIL PALM TRUNK AND RUBBERWOOD SAMPLES INDUCED BY HEAT TREATMENT AT DIFFERENT TREATMENT TEMPERATURES

\begin{tabular}{cccccc}
\hline Species & $\begin{array}{c}\text { Treatment } \\
\text { temperature } \\
\left({ }^{\circ} \mathbf{C}\right)\end{array}$ & $\Delta \mathbf{L}^{*}$ & $\Delta \mathbf{a}^{*}$ & $\Delta \mathbf{b}^{*}$ & $\Delta \mathbf{E}^{*}$ \\
\hline Oil palm trunk & 180 & -30.65 & +10.31 & +9.21 & 33.71 \\
& 200 & -52.25 & +8.21 & -4.32 & 53.14 \\
Rubberwood & 220 & -59.93 & -1.40 & -5.98 & 60.23 \\
& 180 & -22.95 & +11.31 & +8.11 & 27.41 \\
& 200 & -30.96 & +13.99 & +7.27 & 34.88 \\
& 220 & -41.95 & +6.31 & -4.70 & 42.75 \\
\hline
\end{tabular}

Note: $\Delta \mathrm{L}^{*}$ - Lightness, $\Delta \mathrm{a}^{*}$ - green-red, $\Delta \mathrm{b}^{*}$ - blue-yellow, $\Delta \mathrm{E}^{*}$ - colour changes. 
Moisture is the most prominent factor in promoting fungal growth in wood. Most studies have shown that the conversion of hydrophilic nature of wood to hydrophobic through thermal treatment is the key reason for the improved fungal decay resistance (Weiland and Guyonnet, 2003; Li et al., 2017). Previous study by Lee et al. (2017) revealed that the equilibrium moisture content of the oil heat treated particleboards reduced from 6.75 $\pm 0.35 \%$ to $3.87 \pm 0.02 \%$ for OPT particleboard and $6.60 \pm 0.04 \%$ to $4.28 \pm 0.29 \%$ for RW particleboard. As the hygroscopicity of the samples is reduced, the fungal growth is also expected to be reduced. The main function of moisture exists in wood is to facilitate the transportation of diffusible agents from fungi into the wood cell wall (Thybring, 2013). By excluding or reducing the moisture from wood through thermal treatment, the ingress of fungi into the cell wall was obstructed. Apart from that, the degradation of hemicellulose, generation of toxic
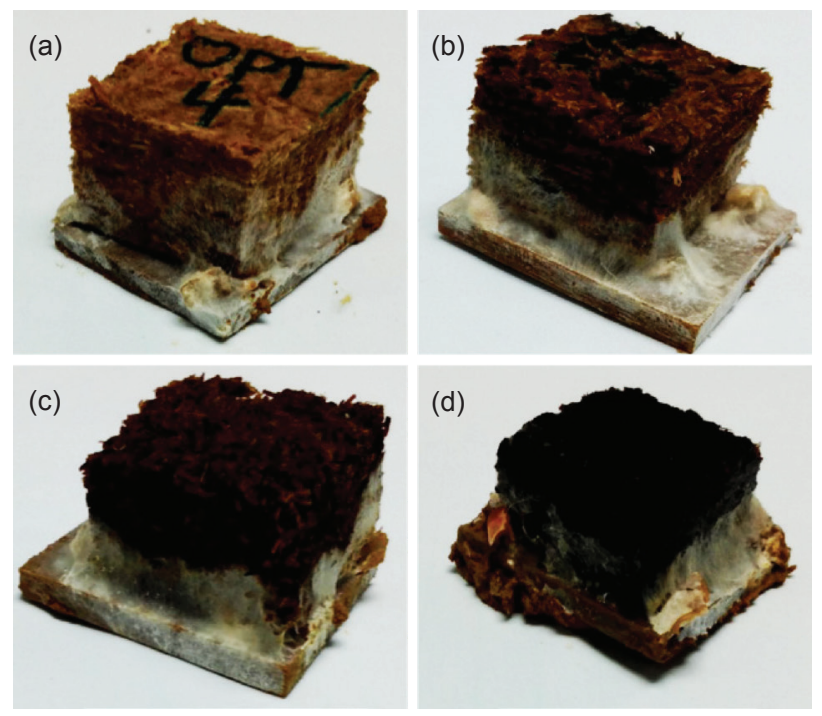

Figure 2. Visual appearance of oil palm trunk (OPT) particleboard treated at (a) control, (b) $180^{\circ} \mathrm{C}$, (c) $200^{\circ} \mathrm{C}$ and (d) $220^{\circ} \mathrm{C}$ after exposure to Pycnoporus sanguineus.

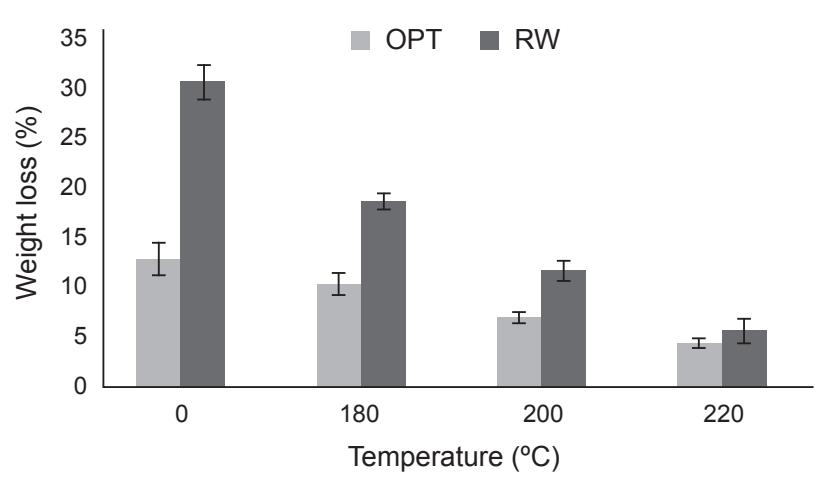

Figure 4. Weight loss of oil palm trunk (OPT) and rubberwood (RW) particleboard after exposure to Pycnoporus sanguineus. substances and increment of acidity of wood during heat treatment are also some probable reasons that contribute to the improvement in fungal decay resistance (Boonstra et al., 2007; Wang et al., 2018).

Figure 5 displays the relationship between $\Delta \mathrm{E}^{*}$ and weight loss caused by white rot fungi. A strong positive correlation $\left(\mathrm{R}^{2}=0.9327\right)$ was found between weight loss and $\Delta \mathrm{E}^{*}$ of OPT samples. On the other hand, the correlation was less strong $\left(R^{2}=0.7527\right)$ for $R W$ samples but still indicated a good correlation between weight loss and $\Delta \mathrm{E}^{*}$. The results obtained in this study suggested that weight loss decreased as the $\Delta \mathrm{E}^{*}$ values increased. Although several reported studies observed a significant correlation between changes in colour and improvement in durability of wood against fungal decay, it is, however, not necessarily accurate. The colour distribution during thermal treatment is not homogenous and uniform (Esteves et al., 2008).
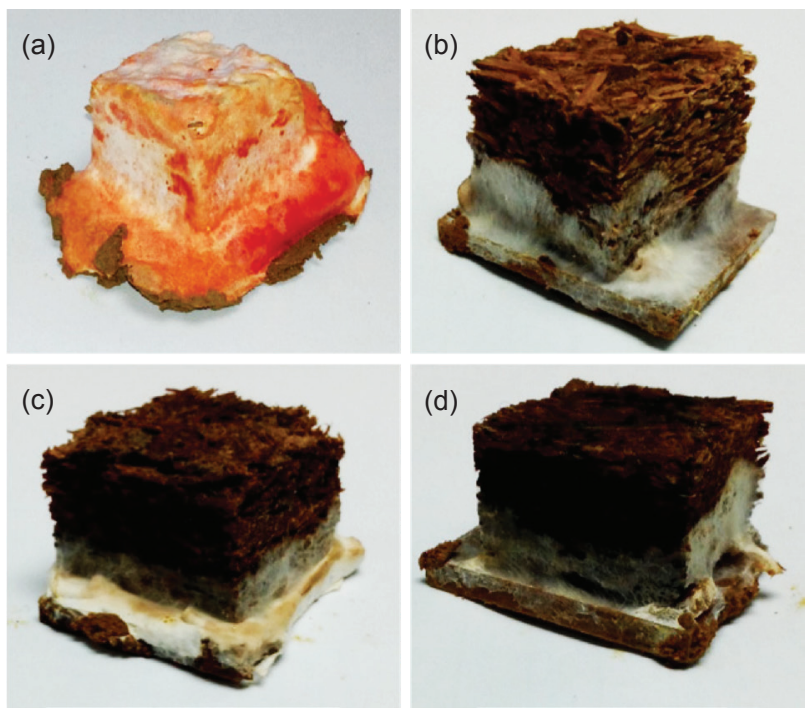

Figure 3. Visual appearance of rubberwood (RW) particleboard treated at (a) control, (b) $180^{\circ} \mathrm{C}$, (c) $200^{\circ} \mathrm{C}$ and (d) $220^{\circ} \mathrm{C}$ after exposure to Pycnoporus sanguineus.

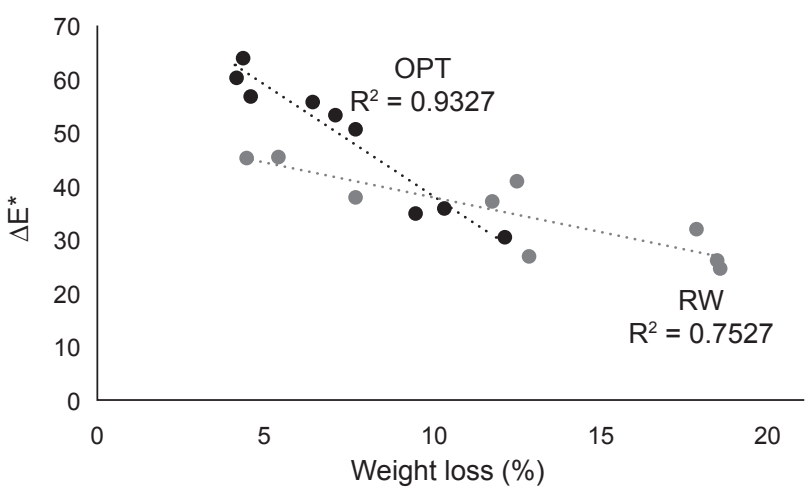

Figure 5. Correlation between weight loss (\%) by Pycnoporus sanguineus and changes in colour $\left(\Delta E^{*}\right)$ of the particleboard samples treated at different temperatures. 
Although the fungal resistance of the treated samples was improved, it should be noted that the oil presented on surfaces of the treated samples might have adverse effect on the gluability when particleboard panels were to be used for thin overlay materials. However, some treatments could be conducted in order to improve the gluability of the particleboard. Sanding and planning could improve the surface wettability of the samples and therefore improve its bonding performance (Wang and Stirling, 2008). Apart from that, plasma treatment aiming to remove the excessive oils could also be applied to enhance its surface wettability and subsequently lead to better gluability (Jamali and Evans, 2008).

\section{CONCLUSION}

Thermally treated particleboard exhibited significant changes in colour and improvement in fungal resistance. Heat-induced darkening can be observed on the sample surfaces and the extent of darkening increased along with increasing treatment temperature. The lightness $\left(\mathrm{L}^{*}\right)$ of the particleboards reduced after thermal treatment. Generally, particleboard samples become redder and more yellow when subjected to thermal treatment. Nevertheless, when subjected to higher temperature $\left(220^{\circ} \mathrm{C}\right)$, the samples become bluer. Improvement in fungal decay resistance were observed as the weight loss of untreated OPT samples reduced from 12.97 $\pm 1.62 \%$ to $4.58 \pm 0.44 \%$ when treated at $220^{\circ} \mathrm{C}$. The treatment effectiveness is temperature dependent as higher treatment temperature resulted in better fungal resistance. RW samples were found to be less resistant to fungal attack compared to that of the OPT samples, probably due to its higher hygroscopicity and higher lignin content that provide more favourable environment for the growth of white rot fungus. Nevertheless, after heat treatment, RW showed better improvement (weight loss from $30.71 \% \pm 1.75 \%$ to $5.78 \% \pm 1.23 \%)$ than OPT. Strong positive correlations $\left(\mathrm{R}^{2}=0.9327\right.$ and 0.7527 for OPT and RW, respectively) were found between weight loss and $\Delta \mathrm{E}^{*}$, suggested that the fungal resistance improved along with increasing magnitude in $\Delta \mathrm{E}^{*}$ values. The results suggested that the colour changes could be a reliable prediction tool for the researchers to have a rapid quantification of the extent of decay resistance. However, it should be noted that it is species dependent and further researches for validation are needed.

\section{ACKNOWLEDGEMENT}

The authors wish to thank for the financial support provided by Geran Universiti Putra Malaysia (GP) GP/2017/9575500 and Higher Institutions' Centre of Excellence (HICoE), Project code: UPM/ INTROP/100-13/9/3/HICoE/ 6369107.

\section{REFERENCES}

Bekhta, P and Niemz, P (2003). Effect of high temperature on the change in colour, dimensional stability and mechanical properties of spruce wood. Holzforschung, 57: 539-546.

Boonstra, M; Van Acker, J; Kegel, E and Stevens, M (2007). Optimisation of a two-stage heat treatment process: Durability aspects. Wood Science and Technology, 41(1): 31-57.

Calonego, F W; Durgante Severo, E T and Furtado, E L (2010). Decay resistance of thermally-modified Eucalyptus grandis wood at $140^{\circ} \mathrm{C}, 160^{\circ} \mathrm{C}, 180^{\circ} \mathrm{C}$, $200^{\circ} \mathrm{C}$ and $220^{\circ} \mathrm{C}$. Bioresource Technology, 101: 93919394.

Candelier, K; Thevenon, M F; Petrissans, A; Dumarcay, S; Gerardin, P and Petrissans, M (2016). Control of wood thermal treatment and its effects on decay resistance: A review. Annals of Forest Science, 73(3): 571-583.

Chung, W; Wi, S; Bae, H and Park, B (1999). Microscopic observation of wood-based composites exposed to fungal deterioration. J. Wood Science, 45: 65-68.

De Melo, R R; Stangerlin, D M; Campomanes Santana, R R and Pedrosa, T D (2015). Decay and termite resistance of particleboard manufactured from wood, bamboo and rice husk. Maderas: Ciencia y tecnología, 17(1): 55-62.

Dubey, M K; Pang, S and Walker, J (2011). Effect of oil heating age on colour and dimensional stability of heat treated Pinus radiata. European J. Wood and Wood Products, 69: 255-262.

Dubey, M K; Pang, S and Walker, J (2012). Changes in chemistry, color, dimensional stability and fungal resistance of Pinus radiata D. Don wood with oil heat-treatment. Holzforschung, 66(1): 49-57.

Esteves, B; Marques, A V; Domingos, I and Pereira, H (2008). Heat-induced colour changes of pine (Pinus pinaster) and eucalypt (Eucalyptus globulus) wood. Wood Science and Technology, 42: 369-384.

Gonzalez-Pena, M M and Hale, M D C (2009). Colour in thermally modified wood of beech, Norway spruce and Scots pine. Part 1: Colour evolution and colour changes. Holzforschung, 63: 385-393.

Hakkou, M; Pétrissans, M; Gérardin, $\mathrm{P}$ and Zoulalian, A (2006). Investigations of the reasons for fungal durability of heat-treated beech wood. Polymer Degradation and Stability, 91: 393-397. 
H'ng, P S; Wong, L J; Chin, K L; Tor, E S; Tan, S E; Tey, B T and Maminski, A (2011). Oil palm (Elaeis guineensis) trunk as a resource of starch and other sugars. J. Applied Sciences, 11: 3053-3057.

Howell, C; Paredes, J J and Jellison, J (2009). Decay resistance of hot water extracted oriented strandboard. Wood and Fiber Science, 41: 201-208.

Jamali, A and Evans, P D (2008). Plasma Treatment of Oil-modified MPB Wood. Final report prepared for FPInnovations - Forintek Division. Quebec, Canada. p. $49-58$.

Kamdem, D P; Pizzi, A and Jermennaud, A (2002). Durability of heat-treated wood. Holz Roh Werkst, 60: 1-6.

Lacic, R; Hasan, M; Trajkovic, J; Sefc, B; Safran, B and Despot, R (2014). Biological durability of oil heat treated alder wood. Drona industrija, 65: 143-150.

Lee, S H; Zaidon, A; Ang A F and Juliana, A H (2017). Dimensional stability of heat oil-cured particleboard made with oil palm trunk and rubberwood. European J. Wood and Wood Products, 75(2): 285-288.

Lee, $\mathrm{S} \mathrm{H}$; Zaidon, A; Lum, W C; Juliana, A H; Ang, A F; Tan, L P; Chin, K L and Paridah, M T (2018a). Thermal treatment of wood using vegetable oils: A review. Construction and Building Materials, 181: 408419.

Lee, S H; Ashaari, Z; Ang, A F; Halip, J A; Lum, W C; Dahali, R and Halis, R (2018b). Effects of two-step post heat-treatment in palm oil on the properties of oil palm trunk particleboard. Industrial Crops and Products, 116: 249-258.

Lee, S H; Ashaari, Z; Lum, W C; Ang, A F; Halip, J A and Halis, R (2018c). Chemical, physico-mechanical properties and biological durability of rubberwood particleboards after post heat-treatment in palm oil. Holzforschung, 72(2): 159-167.

Li, T; Cheng, D; Avramidis S; Walinder, M E P and Zhou, D (2017). Response of hygroscopicity to heat treatment and its relation to durability of thermally modified wood. Construction and Building Materials, 144: 671-676.

Okino, E Y A; Resck, IS; Santana, MAE; Cruz, C LSC; Santos, P H O and Falcomer, V AS (2010). Evaluation of wood chemical constituents of Hevea brasiliensis and Cupressus decomposed by Gloeophyllum striatum using CP/MAS 13C NMR and HPLC techniques. J. Tropical Forest Science, 22(2): 184-196.

Reinprecht, L; Izdinsky, J and Vidholdova, Z (2018). Biological resistance and application properties of particleboards containing nano-zinc oxide. Advances in Materials Science and Engineering, 2018: 2680121.

Salca, E; Kobori, H; Inagaki, T; Kojima, Y and Suzuki, $S$ (2016). Effect of heat treatment on colour changes of black alder and beech veneers. J. Wood Science, 62: 297-304.

Srinivas, K and Pandey, K K (2012). Effect of heat treatment on color changes, dimensional stability, and mechanical properties of wood. J. Wood Chemistry and Technology, 32: 304-316.

Sulaiman, O; Awalludin, M F; Hashim, R and Mondal, M I H (2012). The effect of relative humidity on the physical and mechanical properties of oil palm trunk and rubberwood. Cellulose Chemistry and Technology, 46(5-6): 401-407.

Thybring, E E (2013). The decay resistance of modified wood influenced by moisture exclusion and swelling reduction. International Biodeterioration $\mathcal{E}$ Biodegradation, 82: 87-95.

Toker, H; Baysal, E; Turkoglu, T; Kart S; Sen, F and Peker, H (2016). Surface characteristics of oriental beech and scots pine woods heat-treated above $200^{\circ} \mathrm{C}$. Wood Research, 61(1): 43-54.

Umar, I; Zaidon, A; Lee, S H and Rasmina, H (2016). Oil-heat treatment of rubberwood for optimum changes in chemical constituents and decay resistance. J. Tropical Forest Science, 28: 88-96.

Wang, J and Stirling, R (2008). Coatability of Oilthermal-treated Post-MPB Lodgepole Pine Sapwood. Final report prepared for FPInnovations - Forintek Division. Quebec, Canada. p. 1-14.

Wang, Y; Zhang, Z; Fan, H and Wang, J (2018). Wood carbonization as a protective treatment on resistance to wood destroying fungi. International Biodeterioration \& Biodegradation, 129: 42-49.

Weiland, J and Guyonnet, R (2003). Study of chemical modifications and fungi degradation of thermally modified wood using DRIFT spectroscopy. Holz als Roh-und Werkstoff, 61: 216-220. 